This is a pre-copyedited, author-produced version of an article accepted for publication in the $\underline{\text { Journal of Social }}$ History following peer review. The version of record is due to be published in the Summer 2018 (51:4) edition of the journal.

\title{
"A Fascinating Show for John Citizen and his Wife:" Advertising Exhibitions in Early Twentieth-Century London
}

\section{James Taylor, Lancaster University}

One late November morning in 1920 crowds began to gather outside White City in Shepherd's Bush, lured by what had been billed as "London's brightest event this winter."1 At noon, with what the Daily News reporter thought must be "among the longest queues ever seen even in London" assembling outside, a speech by President of the Board of Trade, Sir Robert Horne, opened the International Advertising Exhibition. ${ }^{2}$ Nine thousand people passed through the turnstiles in the first hour, keen to experience a range of attractions including a model Shopping Street, a Poster Street featuring a collection of the best examples of the art, and a lucky dip competition with 100,000 prizes. The press described it as "one of the jolliest shows that has ever been held at Shepherd's Bush."3

This exhibition was the largest in a succession of shows beginning in 1899 designed to improve the reputation of advertising, enhance the collective identity of the industry, and drum up business. ${ }^{4}$ Tackling the public image of advertising became a pressing need from the late Victorian years. Facing an organized pressure group, the Society for Checking the Abuses of Public Advertising, formed in 1893 to secure legislation protecting the environment from advertising, and a public discourse in which advertising was frequently cast as vulgar, dishonest, and wasteful, advertisers began to coordinate a response. ${ }^{5}$ Taking the lead were advertising agents, who were growing in number and importance in the late 
nineteenth century. ${ }^{6}$ Hitherto chiefly concerned with buying space, agencies were now offering a wider range of services, including creative ones, to firms wishing to advertise. ${ }^{7}$ With this growth came a desire for status, and from an early stage, agents sought to improve their public profile. One method was to go into print with alternative representations of advertising as a serious and productive business pursued by professionals. S. H. Benson, whose agency represented a number of big firms including Bovril and Rowntrees, was a prominent example, penning Wisdom in Advertising (1901) and Force in Advertising (1904). ${ }^{8}$

But such texts reached only small numbers of readers, and other possibilities for communication were opening up, among them exhibitions. Richard Altick concludes his magisterial history of London's exhibitions by observing that the two appetites which these events fed - amusement and instruction - separated after 1851's Great Exhibition, with entertainment increasingly supplied by theatres and music halls, and education provided by government. But his argument that "the age of exhibitions was succeeded by the age of public museums" is misleading. ${ }^{9}$ In fact, the public's penchant for exhibitions remained strong, and the second half of the nineteenth century saw the development of a suburban exhibition circuit of large purpose-built venues servicing popular demand, including the reconstructed Crystal Palace in Sydenham (1854), the Agricultural Hall in Islington (1862), Olympia (1886), and Earls Court (1887), both in Kensington. ${ }^{10}$

Though these venues hosted an eclectic variety of shows, including the kinds of popular spectacles which had been popular in the capital since early modern times, from the late nineteenth century they also accommodated a new form of entertainment: the trade exhibition. A wide variety of businesses had of course been prominent in earlier international expositions celebrating the productivity of industrial capitalism, including the major exhibitions of 1851,1862 , and $1871-4$, but they began to see benefits in presenting themselves to the public in their own exhibitions. Industries with image problems were 
among the earliest adopters. Gas companies handicapped by the widespread perception that gas was unreliable, dangerous, and expensive, and food producers struggling to combat accusations of adulteration, both turned to exhibitions in the 1870 s and 1880 s to counter these negative associations. ${ }^{11}$ Exhibitions were also a great way for firms pioneering new technologies to showcase their wares to the public, with bicycles and motor cars prominent examples. ${ }^{12}$ By the early twentieth century, regular programs of trade shows had become central to the economic viability of London's exhibition halls. ${ }^{13}$

Historians have largely failed to recognize trade exhibitions as an important part of the increasingly commercialized leisure scene of these years, and as crucial spaces in the development of modern consumer culture. ${ }^{14}$ But these were genuinely popular spectacles. There were no rigid distinctions between trade shows and shows for the wider public, with exhibitions regularly attracting mixed audiences even when they were chiefly intended for a business clientele. ${ }^{15}$ This might seem peculiar, but exhibitions could turn almost anything into a compelling spectacle: 1909's Business Exhibition at Olympia featured a speed typewriting competition which transfixed the audience: "the sight of the watching crowds," wrote The Times, "might have led an uninitiated onlooker to suppose that an event of world-wide importance was about to take place." ${ }^{16}$ Mixing education, entertainment, and commerce in varying proportions, exhibitions appealed to urban audiences with more time and money at their disposal, and were versatile means of communication for businesses, who could present what they did to multiple publics at once. ${ }^{17}$ Moreover, in providing a space in which firms could gather, exhibitions also furnished businessmen with a means of developing a sense of collective identity and shared values.

Advertising exhibitions have experienced the same historiographical neglect as trade exhibitions more generally. The most sustained treatment to date is a chapter by Stefan Schwarzkopf, which explores the messages the exhibitions sought to get across, and how they 
evolved over the interwar period. ${ }^{18}$ Schwarzkopf is chiefly interested in exhibitions as part of advertising's wider attempts to promote itself, in particular by annual conventions and publicity campaigns in newspapers and on the hoardings. Although exhibitions can be read for content in this way, this article is more interested in the exhibition as a distinctive form of communication. Exhibitions are interactive experiences, "public, mass-oriented, collective," and as such are potentially more influential than shared reading experiences in shaping attitudes. ${ }^{19}$ Their blend of education and entertainment is particularly worth studying: far from distracting from the serious educational message, the entertainments allowed the message to be conveyed in innovative and powerful ways. ${ }^{20}$ And when this fusion had a clear commercial goal, exhibitions offer valuable evidence for understanding the development of modern consumer culture.

Advertising exhibitions were unlike other trade shows, however. While other industries had commodities to display, advertising did not produce commodities of its own, only two-dimensional representations of them. Simply filling an exhibition hall with these representations would make a gallery, not an exhibition. Examining how advertisers rose to the challenge of translating advertising into three dimensions is the subject of this article. After a brief overview of the sequence of exhibitions from 1899 to 1933 , the article explores the significance of these events through three key themes. ${ }^{21}$

Branding is the first theme. The exhibitions sought to change how the public viewed branded goods. The popular view was that branding increased the price of goods, and was a means of palming off low-quality products onto shoppers. Exhibitions gave advertisers new ways of personifying and domesticating brands. Brands were animated in the form of "living posters" featuring well-known advertising characters which populated the exhibition space, and were placed in the domestic sphere in the shape of the "Advertisers' House," both of which encouraged exhibition-goers to form more intimate relationships with branded goods. 
If people could be induced to trust brands, then advertising's role as the chief intermediary between buyer and seller was cemented.

The second theme is modernity. The exhibitions aligned advertising with modern, progressive values, presenting it not as the preserve of quacks and charlatans, but as a professional, organized business. This message was conveyed visually by breaking with the "chaotic-exotic" style which had characterized major exhibitions in favor of a sparer, more uniform aesthetic. This style projected a vision of a modern, ordered capitalism in which advertisers played a central role, while attractions like "The Shop of 1950" permitted exhibition-goers to perform their role as rational, efficient consumers in this new system.

Exposure is the third theme. Though the exhibitions sought to stimulate desire, they did not try to induce the "numbed hypnosis" which was the hallmark of the earlier international expositions. Rather, they boldly exposed the secret workings of advertising to public view, from the machines which printed the advertisements to the copywriters who invented the slogans. The aim was to get exhibition-goers to appreciate the scale and sophistication of the modern machinery of advertising, and to understand their role in this system. Yet such an approach divided advertisers, with some fearing that the exhibitions were giving too much away, encouraging a critical stance towards advertising.

The final section assesses the reception of the exhibitions and notes that although they were highly successful when judged by volume of press coverage and numbers of visitors, they did not survive as public events in the post-1945 world. While the precise reasons for this are debatable, one factor was growing uncertainty about the wisdom of exposing the industry to the public gaze. Some things, perhaps, were best left hidden.

\section{$\underline{\text { Advertising exhibitions, 1899-1933 }}$}


Though several cities had hosted small exhibitions of advertising art in the 1890s, mostly organized by collectors, leading advertising agent S. H. Benson had a grander vision: to use the exhibition form to display advertising in the round. ${ }^{22}$ With the support of several leading firms, including A. and F. Pears, Lever Brothers, and Bovril, together with the biggest names in the newspaper industry, Benson was able to collect together in one place examples of practically every form of modern publicity, from newspaper and magazine adverts, show cards, and window dressing, to posters, omnibus and tram advertising, and electric signs. ${ }^{23}$ While the promoters had organized the exhibition, which ran for a fortnight at Niagara Hall, Westminster, "with a view of attracting the man in the street," the main aim was to win over businessmen to the idea of advertising. ${ }^{24}$ The metropolitan location was significant: as well as being home to the largest advertising agencies, proximity to Fleet Street guaranteed the extensive press coverage needed to reach as large an audience as possible. ${ }^{25}$

Though conceived as an annual event, Benson did not follow up his exhibition, and while the Crystal Palace hosted the impressive-sounding First International Advertisers' Exhibition the following year, this was in fact a celebration solely of poster art organized by the poster interests. ${ }^{26}$ The idea of a general advertising exhibition was not abandoned, however, and soon returned in a different guise. The Organiser, a monthly magazine founded in 1907 promoting system and organization in modern business, held in July that year the first of what for the next few years was an annual Business Exhibition at Olympia. ${ }^{27}$ From the start, advertising was an important element, with displays of advertisements and competitions for budding copywriters. ${ }^{28}$ To reflect this, in its fourth year in 1910 the exhibition was renamed "The Business and Advertising Exhibition," and hosted an advertising conference. ${ }^{29}$ Though businessmen were the chief target, a dual audience was envisaged: visitors to the exhibition, noted The Times, "whether attracted thither by business zeal or idle curiosity, will find much to interest or amuse." ${ }^{30}$ 
However, Advertising World (hereafter World), a trade paper founded in 1901, noted that despite the exhibition's new name, only a small number of exhibits were really concerned with advertising. ${ }^{31}$ This inspired the magazine to organize its own exhibition exclusively for the advertising industry, held over six days in Westminster's Royal Horticultural Hall in December 1912. The exhibition was for the business visitor - its stated object was "to create new advertisers." 32 And at a time when advertising clubs were a rarity and there were no advertising conventions, it had an important social function, providing the opportunity for "a great gathering of the advertising clans.",33

The event was sufficiently popular for the World to plan a follow-up event, but in the meantime its new rival, Advertiser's Weekly (hereafter Weekly), established in 1913, stepped in, announcing that it would hold its own exhibition in October that year. It had been a squeeze to fit the 1912 exhibition's 74 stands into the Royal Horticultural Hall, so the Weekly booked a bigger venue, Kensington's Holland Park Hall, for its show, which was the most ambitious advertising exhibition yet. ${ }^{34}$ Though the Weekly wanted the exhibition to "make a spectacular appeal to the general public," like its predecessors, its fundamental purpose was to win new business, and to act as a "Representative Assembly" bringing together as many different parts of the industry as possible. ${ }^{35}$ The Weekly envisaged the exhibition as a yearly trade show, noting that "[e]very trade of any magnitude runs an exhibition annually," but when the World's second exhibition was held in 1914, again at Holland Park Hall, there were signs that exhibition fatigue was setting in. ${ }^{36}$ Though Printers' Ink was impressed by the number of international exhibitors, it observed that the exhibition was "somewhat similar" to the two recent events, and it received only passing mentions in the mainstream press. ${ }^{37}$

When the advertising exhibition returned after the Great War, it was with a new sponsor and a grander vision which would set the tone for subsequent events. Organized by the Thirty Club, a London dining club for advertisers, 1920's International Advertising 
Exhibition was far larger than all previous exhibitions, with 319 paid-for stands. ${ }^{38}$ White City had hosted major pre-war events such as the Franco-British Exhibition and the choice of venue signaled the industry's new-found confidence and ambition. Whereas previous advertising exhibitions had appealed to the general public almost as an afterthought, the organizers realized that for their exhibition to succeed "the first essential ... is to get the public there and interest them." ${ }^{39}$ And although some of the pre-war exhibitions had been opened by London's Lord Mayor, the level of patronage enjoyed by the 1920 exhibition was far greater. The industry had had a good war, helping the state's propaganda efforts, and this led to high-profile government support, with the President of the Board of Trade and several other government ministers attending. ${ }^{40}$ The exhibition received the most prestigious endorsement possible when the King and Queen visited on the Friday morning.

Despite calls for the exhibition to become a yearly event, the industry, perhaps mindful of the diminishing returns which had set in before the war, held back. ${ }^{41}$ The establishment of the advertising convention as an annual fixture in 1925, giving advertisers an opportunity to socialize and exchange ideas, also made regular exhibitions less urgent. ${ }^{42}$ As a result, the next full-scale advertising exhibition did not take place until $1927 .{ }^{43}$ While the overarching theme of White City had been advertising as the solution to the post-war slump, the 1927 exhibition capitalized on the government's recent establishment of the Empire Marketing Board (EMB) by presenting advertising as the means of regenerating empire. ${ }^{44}$ Organizational duties were taken over by the recently-formed Advertising Association, a body established to represent the industry as a whole, and the event was switched to Olympia in July. ${ }^{45}$ Though some businessmen had felt that large crowds in 1920 had made it difficult to transact serious business, once again the organizers made a concerted pitch to the general public with an enhanced Shopping Street (nicknamed "Baby Bond Street"), a Poster Academy, and a huge EMB stand covering 10,000 square feet, which 
included a demonstration kitchen preparing empire foodstuffs for visitors. ${ }^{46}$ And, as in 1920 , the exhibition enjoyed prominent patronage. Leo Amery, Secretary of State for the Colonies, opened the exhibition, while the Duke of York gave the exhibition the royal seal of approval. $^{47}$

The final major interwar exhibition followed in 1933, with the same sponsor, venue, and again taking place in July. ${ }^{48}$ There were the familiar debates about whether courting the general public undermined the event's serious business objectives, with one correspondent of the Weekly urging the organizers to get rid of the "trappings and the tinsel" aimed at bringing in the "riff-raff." ${ }^{49}$ But as before, this was a minority view, and 1933 stuck with the formula of the previous two exhibitions in providing crowd-friendly features such as the Advertisers' Playground, consisting of an amphitheater, lawn, and "Sport-a-pool" featuring regular displays of dancing, swimming, and calisthenics. With the EMB being wound down, empire was a more muted - though still present - theme than in $1927 .{ }^{50}$ Instead, the focus was how advertising could combat the Depression. As Sir William Crawford, head of one of the country's leading agencies and chairman of the organizing committee, bullishly put it: "You have all read of the exhibition of 1851 which changed the whole flow of British enterprise and trade. This exhibition is going to do the same." ${ }^{\text {51 }}$ Once more there was an impressive display of official patronage, with Lord Derby opening the exhibition, and a host of illustrious visitors appearing during the week, including the King and Queen, the Prince of Wales, and Postmaster General Sir Kingsley Wood.

These exhibitions were part of an international phenomenon. "Art in advertising" was the theme of a series of exhibitions held in New York between 1908 and 1910, which became annual events under the auspices of the Art Directors Club in 1921, and of major exhibitions in Amsterdam in 1917 and $1935 .{ }^{52}$ Exhibitions also grew out of the advertising convention movement, which developed earlier in other nations than Britain. So, the Pacific Coast 
Advertising Men's Association organized an exhibition as part of their San Francisco Convention in 1910, reaching an audience of 35,000, and exhibitions became a regular feature of the annual conventions sponsored by the Associated Advertising Clubs of the World in the 1910s. ${ }^{53}$ More work is needed to explore this global picture, but the organizers of the British exhibitions certainly believed that their exhibitions were bigger and better than those held elsewhere. ${ }^{54}$ Indeed, there is evidence that foreign visitors came away impressed: Louis Wiley, advertisement director for the New York Times, called the 1927 exhibition "a great inspiration to America ... We have never done anything on this scale. It ... is one of the most beautiful things I have ever seen." ${ }^{, 55}$ Britain's advertising exhibitions, then, were not a US import, but an expression of a British advertising identity. ${ }^{56}$

\section{Brand loyalty}

The central purpose of these exhibitions was to fix advertising's place in modern business as the crucial intermediary between buyer and seller. Advertising was "the bond of confidence" between manufacturer and consumer, "the willing servant of the business man," and "the guide of the great buying public." ${ }^{57}$ Advertising could act as a commercial lubricant by spreading trust, convincing shoppers that they were protected when buying a branded item, and reassuring retailers that they were not putting dubious stock on their shelves. ${ }^{58}$ But for this system to work, advertisers had to transform people's perceptions of branded goods, and therefore their shopping habits. This highlights a subtle but important distinction between advertising exhibitions and their predecessors: whereas exhibitions since 1851 had celebrated commodities, advertising exhibitions celebrated branded commodities. So, while there is much work which explores the "fetishization" or "spectacularization" of the commodity in 
the great exhibitions, this does not entirely explain what was happening at the advertising exhibitions. $^{59}$

Branding at this time was a mystery to many: as leading advertising agent Charles Higham, chairman of the 1920 organizing committee, commented, "there are millions of people who have not to-day the faintest idea why people trade mark their goods, what are the advantages of it, and why they should ask for a thing by a printed name. ${ }^{\prime 60}$ It was widely believed that branding increased prices, and that its main purpose was to foist inferior goods onto the public. ${ }^{61}$ The exhibitions needed to challenge these attitudes, getting people to view brands as a guarantee of quality, reliability, and economy. "A man buying a gold ring looks for the hall-mark. We want to make this principle apply to all kinds of commodities," explained another of the organizers of $1920 .^{62}$ To this end, slogans such as "Trade-marked goods are hall-marked goods," and "You'll never be stranded by articles branded," were posted around the main hall. ${ }^{63}$

But the exhibitions also had more subtle methods of encouraging people to trust brands. Although the second half of the nineteenth century had seen the development of a number of brands for a range of household goods, Schwarzkopf notes that advertising agencies had initially paid little attention to "the idea of the symbolic and emotional capacities of brands in building consumer loyalty." ${ }^{64}$ This, he argues, began to change in the early twentieth century. A US guide to trademarks issued by the J. Walter Thompson agency in 1911 recognized the power of "advertising characters" to impart life to a brand. ${ }^{65}$ By this point, a number of advertising characters had achieved a degree of recognizability, and this presented an opportunity first seized at the 1913 exhibition. Twice daily, models dressed as famous figures in advertising were displayed in "living tableaux" form, including Johnnie Walker, the Kodak Girl, Bibendum (the Michelin Man), and Dirty Dick, the Pears' Soap tramp. ${ }^{66}$ These "living posters" attracted much attention from visitors, and the idea was 
enlarged for 1920. On the Saturday before the official opening of the exhibition, London was treated to the mile-long "Great Publicity Parade," featuring 150 exhibits on foot and on decorative floats, many of them representing advertising characters (see Figure 1). ${ }^{67}$

\section{<Insert Figure 1 near here>}

Scenes from the publicity parade of 1920. Illustrated London News, December 4, 1920, 927. (c) Illustrated London News Ltd / Mary Evans Picture Library.

Though on one level simply a publicity stunt designed to attract attention, the parade also had the serious objective of encouraging an intimate connection between the advertising characters and the audience. These were characters who had been part of people's lives "from the cradle," wrote the Morning Post, and familiarity with them was something shared by everyone, binding the nation together: "tens of thousands of small children stood mute with pure joy" as the pageant passed, but their "delight was shared by hundreds of thousands of fathers and mothers, sisters and brothers, and uncles and aunts." ${ }^{\text {68 }}$ The Star noted that the procession brought together "all sorts and conditions of people:" even class differences dissolved in shared affection for these democratic characters. ${ }^{69}$

The parade was not simply a spectacle, but an opportunity for interaction, promoting further intimacy. The organizers claimed that the parade would "put the general public on speaking terms" with advertising characters, and indeed, press coverage of the event highlighted various forms of contact between them. ${ }^{70}$ The Daily Mail reported the figures "throwing merry jests - and samples - to the crowds, who joked back as if with old friends," while the "bright little boy" dressed as "Bubbles" of Pears' Soap fame, "had much to do to escape the kisses of the womenfolk." ${ }^{, 71}$ When the crowd recognized a particular character, they shouted out the relevant slogan, and even the trade press seems to have been taken aback 
by the popular response to the pageant, noting that the affection entertained by the public for these characters was a highly significant industry achievement. ${ }^{72}$

The popularity of the "living posters" ensured that they remained core to subsequent exhibitions. While 1933's event was heralded by another pageant, 1927 saw a variant, the Palace of Beauty. Inspired by the attraction of the same name at Wembley's British Empire Exhibition of 1924-25, which featured ten women dressed as celebrated beauties from history, the 1927 Palace consisted of a series of sixteen archways each containing a recreation of a well-known advert featuring a beautiful woman. ${ }^{73}$ Part of the purpose was the aesthetic appeal, to demonstrate "how beauty and dignity may be, and are, combined in modern advertising." ${ }^{74}$ But more than that, the Palace aimed to change people's relationship with brands. As with the parades, the close relationship between consumer and brand character was stressed in descriptions of the Palace, though this time there was a romantic element: "Drawings of girls with whom everyone has fallen in love when waiting on Tube platforms or passing along the street here come to life." ${ }^{, 75}$ The aim was to bring these living advertisements as close to the public as possible: whereas the beauties of Wembley posed behind sheets of plate-glass, no such barrier was interposed between the models of 1927 and the public. ${ }^{76}$ The emphasis was on the intimacy of the encounter: "Here you will meet the winsome little lady who informs us that 'Friday night is Amami night,"” while the Kodak Girl "breathes the pleasure to be got from a holiday accompanied by a Kodak.",77 Just as with the publicity parade, the Weekly reported cries of "delighted recognition from men, women and children alike" as they passed along the archways. ${ }^{78}$ As close as the encounter was, however, men who tried to engage the beauties in conversation were rebuffed, and in 1933, the advertising characters were made more accessible, populating the Advertisers' Playground the entire week. ${ }^{79}$ 
The exhibitions thus blurred the boundaries between the fantasy land of advertising and the real world. A London Underground poster advertising the 1920 exhibition showed a tube platform crowded with advertising characters waiting for a train. If the characters had broken the bounds of their adverts and invaded London, the process was two-way: what was to stop Londoners dreaming their way into the adverts? In breaking down the barriers between advertisement and consumer, the poster was, as Richard Hornsey puts it, "an invitation to locate oneself among a merry band of advertising characters, or to effectively join the new spirited society that branded mass consumption was now promising to deliver." ${ }^{80}$ This imagined process was given tangible form in the costume balls which were a feature of the 1920 and 1927 exhibitions. At these, guests were encouraged to come dressed either as an advertising character or as a representation of a brand, with several firms putting up prizes for the best costumes to add an element of competition. ${ }^{81}$ Though 2,000 attended the later ball, expensive ticket prices restricted access to the wealthy. ${ }^{82}$ Nevertheless, more people could turn themselves into advertisements in 1933 with the "film test" competition. After attention from a make-up specialist, entrants were photographed, and each day the most popular shot would win $£ 10$, while the "best advertising face of the week" won $£ 100$. The competition was presented as inclusive: "Old or young, pretty or plain, anyone may have the type of face that will give an idea for an advertisement." ${ }^{, 83}$ Therefore anyone could imagine themselves incorporated into adland, their face on the hoardings or in the magazines. The exhibitions thus positioned advertising as entirely in step with the democratic mass culture of interwar Britain. ${ }^{84}$

Personifying brands was one way to popularize them; another was to bring them into the home. From 1920, every exhibition featured an “Advertisers' House:” a house entirely crafted from and stocked with advertised goods. The 1927 version featured a dining-room, drawing-room, three bedrooms, veranda, kitchen, bathroom, and five miniature gardens, 
containing a total of over 150 "exhibits." ${ }^{85}$ Though clearly borrowing from the Daily Mail's Ideal Home Exhibition, which began in 1908, by using only branded commodities, the emphasis was different: the house presented a vision of a world in which advertising drove material progress. Positioning advertising as the creator of comfort and luxury rather than a parasitic element in the modern economy, the House directly addressed one of the most common critiques of advertising.

The lesson was all the more potent because it placed branded goods at the heart of the domestic sphere. Those who might be skeptical about advertising would see how extensively advertising had "entered into the most intimate details of everyday life." "impress the public with the fact that they are surrounded by advertised articles and live with advertised articles. ${ }^{" 87}$ To hammer home the message, the brand name of each item was displayed in tablet fashion. ${ }^{88}$ Descriptions of the house offered room-by-room walkthroughs which positioned the reader as a guest in a house of branded extravagance: "Music, yes there is an HMV gramophone and a CAV wireless. Warm yourself alongside this Cozy stove. It is efficient as it is handsome. ... Let me offer you a Craven 'A' cigarette." ${ }^{89}$ Such a method of presenting goods - allowing visitors to inhabit these spaces - was much more effective than traditional forms of display, thought the World: "how different they looked there in that setting compared with the impression one gets from the exterior of a shop window!"90 Just as "living posters" removed the barrier of the hoarding separating advertising from the public, so the Advertisers' House removed the barrier of the shop window dividing branded goods from the public. The exhibitions thus gave their organizers unprecedented opportunities to bring brands into the lives of the people, teaching them to trust only branded goods.

\section{$\underline{\text { Advertising and modernity }}$}


Early twentieth-century critics of advertising such as H. G. Wells sometimes presented it, and the quack culture with which it was closely associated, as "vestiges of an irrational past order" which would be swept away by science, rationality, and the age of the expert. ${ }^{91}$ The advertising industry countered this by representing itself as modern and innovative, a running theme of the exhibitions. Technology was always prominent, with a galaxy of wondrous advertising gadgets on display. Visitors to the 1899 exhibition witnessed "the Automaton," a "splendid wax figure of a girl, placed in a kind of pulpit, which leans forward, takes from a box an announcement, and holds it up for the public gaze," while the pageant which announced the 1933 exhibition featured a mobile sky projector capable of projecting advertisements into the night sky. ${ }^{92}$ The exhibitions were also quick to display the advertising potential of cinema: Zenith Films showed their commercials at the 1913 exhibition, and all of the interwar exhibitions featured cinemas with continuous performances. ${ }^{93}$

Modernity was also demonstrated in other ways. Business in the early twentieth century was keen to portray itself as a "uniquely progressive" force, and the exhibitions were a good example of this. ${ }^{94} 1912$ featured a stand staffed entirely by female advertising agents displaying examples of their handiwork, and also hosted a meeting for women in advertising. ${ }^{95}$ In reports of subsequent exhibitions, the large numbers of women involved in the industry was frequently noted. ${ }^{96}$ In addition, the exhibitions sought to convey the scale, science, and professionalism of the industry, to underline that modern advertising was produced by experts, not quacks and showmen, and was an advanced and sophisticated part of the machinery of modern commerce. ${ }^{97}$

The exhibitions' relentless focus on the modern meant that the past, if mentioned at all, often figured as something to be derided. The 1920 exhibition was advertised by means of an old horse-drawn bus driven around London bearing the banner: "Don't live in the past! Come to the Advertising Exhibition and be up-to-date." $" 98$ In order to create a sense of 
progress, the organizers used historical contrasts, a long-standing exhibition device. South Kensington's International Health Exhibition in 1884, for example, had presented an "Old London Street," designed to contrast the shortcomings of the past with the cleanliness of modern streets. ${ }^{99}$ The advertising exhibitions used a similar stratagem. In 1927, Punch's stand juxtaposed advertisements taken from its early issues with more recent examples. The contrast, according to the Weekly, was "as interesting as it is amusing. The difference is so great as to be almost incredible." ${ }^{100}$ In 1933, a stand illustrated the history of poster advertising by contrasting photos of late nineteenth-century hoardings with modern examples, highlighting the difference between the "crudely drawn and crowded" posters of yesteryear with the simple, effective, and rationally displayed modern posters. ${ }^{101}$

The exhibitions' relationship with the past, however, was more complex than this suggests. As Bernhard Rieger and Martin Daunton note, British narratives of modernity, unlike elsewhere in Europe, were more to do with "continuous development" than sudden rupture, and this can be seen in the way that the exhibitions presented the evolution of advertising. ${ }^{102}$ The displays which tracked the development of advertising helped imbue it with a past, a heritage. They emphasized not only how far advertising had come, but also how much of a history it had. Thus, exhibition-goers could enjoy a "Press Museum" containing the first numbers of well-known newspapers dating as far back as 1626, and a "Museum of Advertisements" displaying the earliest advertisements from leading firms. ${ }^{103}$ Such displays anchored present developments in the past, placing advertising in a British tradition of modernity. ${ }^{104}$ Thus, the advertising exhibitions worked in a similar way to other exhibitions which, as Sophie Forgan puts it, supported the narrative of progress while also "confirming the essential unity of past, present, and future."105 Advertising was presented as a thread running through history, connecting the ages. 
Exhibitions also enabled advertising to convey its modernity visually. Organizers wanted to break with the style, described as "chaotic-exotic" by Rosalind Williams, which had hitherto characterized the major exhibitions. The "chaotic-exotic" stressed abundance and luxury, its aim being "not to express internal consistency but to bring together anything that expresses distance from the ordinary," and became the hallmark of exhibitions together with other consumer environments, notably the department store. ${ }^{106}$ But the advertising industry of the twentieth century wanted to strike a different note: chaos smacked too much of the messy hoardings of the Victorian era, and while abundance was good, it needed to be a tamed and managed abundance. Therefore, 1912 was the first of the exhibitions to embody a new aesthetic. The stands were of a uniform design and size, which meant that "the chaotic appearance presented by the majority of exhibitions was happily avoided:" the atmosphere was "light and airy," leading to "a prevailing brightness that made an excellent background for alert exhibitors and keenly interested visitors." ${ }^{\text {"107 }}$ The principle was carried much further in 1927 and 1933 by exhibition designer Joseph Emberton. Hired on the strength of his innovative kiosk designs for the British Empire Exhibition, Emberton was skilled at adapting cutting-edge modernist design to the developing consumer culture. ${ }^{108}$ Symmetry, uniformity, and coherence were his watchwords: Victorian and "Tudorbethan" were definitely out. ${ }^{109}$ His designs proved popular. Amery argued that 1927 was the greatest advertising exhibition ever held because the "very diversity of all the stands has been co-ordinated into one great artistic conception of what advertising means."110 The exhibition's aesthetic echoed trends in modern urban development: the Daily Mail said that visitors would be entering "the world's first advertising city - 'town planned' on modern and bizarre lines:” it was "the most startlingly modern exhibition ever held in London.",111

The exhibition's architectural style had a wider political significance. Emberton's unifying theme helped to project a vision of a modern, ordered capitalism in which 
advertising would play a crucial role. Influenced by growing support for the idea of economic planning in the Depression-struck 1930s, major industry figures like Crawford began to argue that a radical shift to some form of directed economy was necessary for recovery. ${ }^{112}$ " $[\mathrm{M}]$ ore economical and efficient marketing and advertising" was key to the "programme of vigorous national development" which Crawford had in mind, while the advertising industry would also coordinate the "great campaign of national persuasion" necessary to overcome opposition to the new economic policy. ${ }^{113}$ In a suggestive article following Olympia in 1933, the Weekly presented the exhibition as "[a] triumph of Co-ordinated Individualism." The organizer of each sub-committee was left to work in his own way "as long as he worked within the general plan. A sort of Fascist democracy. Westminster might be the more efficient for an application of the Olympian technique."

The exhibition was a particularly effective vehicle for these ideas not only because they could be articulated visually through Emberton's uniform design, but also because visitors could perform their role as rational, efficient consumers in this new ordered capitalism in 1933's star attraction, "Packeteria: The Shop of 1950." This was a self-service shop, with everything sold in packets; assistants were only present in order to operate the cash register and restock the shelves. The chairman of the design committee explained how the shop worked, the plan of which can be seen in Figure 2:

we adopted a lay-out designed to canalise the flow of customers so that they are able to pick out the goods they need. As they enter the shop, via a passometer, they take a tray and place it on a double rail of chromium steel which runs the whole length of the counters above which the merchandise is displayed on three tiers of glass shelves. The tray is so constructed that it slides easily along the rails and the customer has no more to do than to place her packets on the tray. ${ }^{115}$ 


\section{$<$ Insert Figure 2 near here $>$}

Layout of the Shop of 1950. Advertiser's Weekly, July 13, 1933, 56. History of Advertising Trust: $\underline{\text { www.hatads.org.uk. }}$

Though the Weekly was enthusiastic about the shop, it wondered whether "directing the stream of customers by means of chromium-plated railings" would work in the real world: "The Englishwoman queues up with docility, but perhaps the compulsion of steel would be resented." 116 Yet it was one of the biggest draws at the exhibition, perhaps helped by the popular press which described the railings in homely terms as "a little railway along which each customer pushes a train, filling it with goods on the way." ${ }^{117}$ Afterwards, the shop was purchased by Bentalls department store in Kingston upon Thames. A huge crowd gathered before its opening by Crawford, and over 3,000 shoppers passed through the store in the first hour alone. ${ }^{118}$ Shoppers seemed comfortable with the tramlined future planned for them. If the "chaotic-exotic" aesthetic of nineteenth-century exhibitions set the template for the department store, then the severe rationality of the advertising exhibitions neatly prefigured the age of the chain store and supermarket. ${ }^{119}$

\section{Advertising laid bare}

Exhibitions were designed to transform how visitors thought and acted. Just as the British Empire Exhibition would encourage visitors to "learn to think imperially," so the advertising exhibitions sought to mass-produce ideal consumers. ${ }^{120}$ As we have seen, they stimulated desire through devices such as the Advertisers' House - dubbed "the Housewives' Heaven" by the press - while the various shopping displays gave visitors further opportunities to 
fantasize about consumer goods: Amery described Olympia in 1927 as “an Aladdin's Cave" with a "magic power of endowing us with 'desire' and 'the wish to buy.",121

Yet the advertising exhibitions did not seek to induce the "numbed hypnosis" Williams claims was the hallmark of world fairs and other modern environments of mass consumption like department stores and shopping malls. ${ }^{122}$ At the Berlin Industrial Exposition of 1896, Georg Simmel wrote that the crowding together of products "paralyzes the senses" causing a "veritable hypnosis." ${ }^{123}$ But by the early twentieth century, this kind of approach was falling out of favor. In 1909, The Times suggested that exhibitions encouraging visitors to wonder at the productive power of modern capitalism were passé: "we can no longer romanticize collections, however vast, of the industries of all nations."124 The modern public demanded new types of entertainment, and visitors to the advertising exhibitions were given a number of ways to engage actively with - and even to exercise critical judgement on - modern advertising.

Competitions were a regular feature. From 1908, visitors were invited to judge the best posters displayed, with cash prizes for successfully predicting the verdict of the expert panel of businessmen. ${ }^{125}$ Later competitions had a crucial twist, however: now, the experts were side-lined and instead the winner would be the person who successfully forecast the order of merit as determined by the popular vote. ${ }^{126}$ By dispensing with the judging panel, the exhibitions were privileging popular taste above that of the expert. And though competitions helped to legitimize and elevate advertising - the implication being that adverts were works of art, and could be judged as such - competitions also encouraged the public to adopt a critical stance towards advertising. Reports suggested that visitors were not shy of criticizing posters they did not like, and this made some agents question "the policy of making the public conscious critics of advertisements qua advertisements." 
Market research was becoming an established practice in the interwar period, and exhibitions provided both a source of data about consumers and also a means of interesting these consumers in the practice itself. ${ }^{128}$ By 1927 , organizers readily understood that the results of exhibition competitions enabled advertisers to better understand the public's tastes, and advertisements for the 1933 event openly told the public that there were so many prize competitions because "[b]ig advertising firms want your personal opinion of what they have to offer." ${ }^{129}$ Exhibitions offered other ways of finding out about consumers, which could be turned into attractions in their own right. In 1927, Olympia housed "a special mystery stand," where visitors would sit in a darkened room and watch electrically-lit advertisements flashed onto a screen. Afterwards, they would write down what they could remember of the advertisements. Subjects knew they were being tested, but not what the purpose was. ${ }^{130} 4,500$ took the test, indicating that people were happy to act as guinea pigs in the interests of research. $^{131}$

Advertising exhibitions did not follow the pattern established by the nineteenthcentury great expositions of obscuring production in favor of consumption. To unshackle commodities from the context of their production was, it has been widely argued, a key aim of exhibitions from 1851, which were designed "to feature not machines but the things machines were used to make." 132 This "constitution of consumption as a separate sphere, a world apart from production" is often identified as a defining feature of modern capitalism. ${ }^{133}$ Yet the advertising exhibitions followed a different course. Choosing not to focus solely on the advertisements themselves, organizers instead highlighted the processes that went into their creation, in order to demonstrate that advertising was "a soundly established industry." 134 One way of doing this was to bring into public view the technologies that produced the advertising. This was not a drawback in terms of enticing the public, for as exhibition veterans knew, machinery in motion had considerable popular appeal. ${ }^{135}$ At the 
very first exhibition in 1899 , there was a display of color printing, where visitors could see large machines churning out copies of Benson's latest poster for Bovril, together with demonstrations of stereotyping and electrotyping, wood engraving, and line and tone blockmaking. ${ }^{136}$ Machines remained popular: in 1933, the exhibition newspaper, the Daily Review, was produced and printed on site in full view: a "Newspaper with the Lid Off."137

Individual exhibits sought to explain how advertisements were produced. At the Daily Mail's stand in 1912, visitors could "learn, in five minutes, from practical illustrations, the complete story of a great advertisement, adorned with pictures, from the receipt at the office of the simple typescript of the letterpress to its appearance as a full-page announcement." The idea was taken even further by the Daily Chronicle in 1927. Their exhibit, "From Pulp to Purchaser," illustrated "the history of a Chronicle advertisement from its beginning as timber until it reaches its ultimate billet on the breakfast-table as part of a newspaper."139 The aim was to turn the hidden processes behind advertising into a spectacle. While the machines may have exercised a hypnotic effect - in 1927 the Weekly reported that visitors were "vastly fascinated by the linotypes and monotypes and stand for hours 'watching the wheels go round"" - these exhibits were intended to be educational, not numbing. ${ }^{140}$ The appeal was to a rational visitor, who would come away with a new-found appreciation of the solidity and scale of the advertising industry.

As well as displaying machine-production, the interwar exhibitions also highlighted the human factor in the creative process. So, at the Samson Clark agency stand in 1920, "girl copywriters and artists in the nattiest of blue and white overalls worked hard all day along with some of the best-known men in the Service. There was always a crowd watching the production of the advertisements from the first rough ideas to the final lay-out." ${ }^{\text {"141 }}$ Such exhibits turned the creative process into a spectacle, pushing the advertising creatives center stage. In 1927, Higham, now Sir Charles, thought that his agency's stand "lacked a touch of 
life," so he turned himself into an exhibit for an hour every day, sitting at a desk writing “copy for anyone who asks for it, without charge," an attraction which proved very popular. ${ }^{142}$

These strategies imply complex relationships between advertisers and visitors. Exhibitions are sometimes seen as crude instruments of indoctrination, even oppression. Paul Greenhalgh, for example, regards 1851's Great Exhibition as "an immense show of strength designed to intimidate potential insurrectionists." ${ }^{\text {143 }}$ But there are different approaches. Tony Bennett sees exhibitions as displays of power, certainly, but not the kind which tried to "terrorize." Rather they sought to position people on the same side as this power.

To identify with power, to see it as, if not directly theirs, then indirectly so, a force regulated and channelled by society's ruling groups but for the good of all: this was the rhetoric of power embodied in the exhibitionary complex ... This power ... plac[ed] itself on the side of the people by affording them a place within its workings. ${ }^{144}$

Bennett explores this idea in relation to state power, yet business interests were just as alive to the possibilities of exhibitions in this regard. Through its exhibitions, the advertising industry presented itself as a national enterprise in which the entire population was involved. The general public did not merely have a place within the advertising system: the whole system rested on understanding public preferences and tastes and catering to them. Exhibitions thus became celebrations of this collective endeavor, where visitors could see themselves as members of a mass of consumers whose purchasing decisions mattered. Exhibition-goers were encouraged to appreciate advertising's power to influence their own behavior. Olympia in 1927 was "a fascinating show for John Citizen and his wife, who are the targets at which all the artillery of publicity is aimed," wrote the Daily Mail. 
Why are John and his wife eating a little more mustard nowadays than a few months back? At the Club-room of the Mustard Club they will discover what subtle methods have put "mustard" in everybody's mouth. Why does a man buy a certain kind of cigarette? Why do women patronise this shop in preference to that, buy this frock, this face cream, this brand of jam, instead of that? ${ }^{145}$

The language of "targets" and "artillery" framed the encounter as a war of persuasion dedicated to wearing down shoppers' resistance, but other accounts placed the citizenconsumer in the driving seat. The Daily Express wrote that the exhibition furnished "a mirror in which the consumer will see himself as the ultimate potentate whom these experts in psychology and the printed appeal ... are endeavouring to propitiate. He will find it most stimulating both to his intelligence and his self-esteem." ${ }^{\text {"146 }}$ Both versions resonated with the broader climate of post-1918 enfranchisement: it was clear that John Citizen - and his wife now mattered. ${ }^{147}$

Just as the big international exhibitions "sought to make the whole world ... metonymically available in the assemblages of objects and peoples they brought together and ... to lay it before a controlling vision," so the advertising exhibitions attempted to lay advertising bare, allowing visitors to exercise "specular dominance" over the entire industry. ${ }^{148}$ As early as 1913 , exhibitions were promising "to give the public a bird's-eye view" of the trade. ${ }^{149}$ They were presented as an unveiling, a demystification. They were where "[t]he secrets of great advertising campaigns are revealed." ${ }^{150}$ Visiting these exhibitions offered "the fascination of a visit to the engine-room. We can, so to speak, see the wheels go round of that mighty engine of advertising which carries trade along." 151 Actually seeing the advertising industry laid out in this way made the lesson much more vivid than reading about it: as travel writer $\mathrm{H}$. V. Morton put it, even if "the Man in the Street and his all important wife" had no technical interest in the subject, they would "be amused and surprised 
to walk into the mysteries so frankly revealed, and to see themselves as advertisers see them!"152

However, this approach divided the industry, with some insiders convinced that it was dangerous. As early as 1920, some agents wondered "whether it was wise to bring the general public 'behind the scenes' at all."153 And as the exhibitions developed new methods of revealing the mysteries of advertising, some admen became increasingly nervous about the implications. Francis Meynell of Charles W. Hobson thought that

the less the public knows of the processes of advertising, the less the public is enabled to watch itself being persuaded, the more persuasible [sic] it is. The unconscious is better material than the self-conscious. I myself would like the great public to be aware of nothing whatever about advertising - except the advertisements. ${ }^{154}$ Meynell's was not a lone voice. S. J. G. Chipperfield of Palmer, Newbould, and Co. argued that "advertising could only continue to be successful as long as the public, generally speaking, were unaware of the existence of advertising agencies, star copywriters and brilliant layout men." An agency's competence was measured by "the amount of money our advertising transfers from the pockets of the public to the pockets of the advertiser;" as such, it was an error to "flaunt our money-conjuring methods" in the faces of the public. With tongue only slightly in cheek, he asked: "Isn't the holding of an Advertising Exhibition rather like staging a dress rehearsal of a hold-up in full view of the intended victim?"155

The exhibitions therefore highlighted a divide within the industry. Men like Meynell and Chipperfield thought that advertisers should not draw attention to themselves, and instead influence behavior unseen. By contrast, those who supported the exhibitions wanted to boost the status of advertising by presenting it as a modern, sophisticated, trustworthy - and highly visible - element of contemporary commerce. They hoped that demystifying advertising 
would not stop it working, but would make it more effective, by imbuing exhibition-goers with newfound respect for the process and the practitioners.

\section{$\underline{\text { Reception and significance }}$}

It is challenging to recover the experiences of visitors to the advertising exhibitions. In the absence of direct evidence, responses are mediated through the trade and the mainstream press, and these are problematic sources. Newspapers, heavily dependent on advertising revenue, were enthusiastic promoters of anything which would encourage more firms to advertise in the press, and therefore "bought in" to the advertising exhibitions, paying for stands and disseminating the exhibitions' messages in their columns. Even the left-wing Daily Herald, less dependent on advertising than most of its tabloid rivals, happily promoted the exhibition line, a 1927 leader informing its readers that although advertising could sometimes be "used for base purposes," it was "one of the most successful methods that man has yet devised for the broadcasting of ideas" and was "an inevitable accompaniment of human progress." 156

However, some points can be made. The exhibitions were well-attended. The 1899 event, open for ten days, attracted 14,000 visitors, but numbers for the interwar exhibitions were considerably higher. ${ }^{157}$ The 1920 exhibition drew 261,000 visitors. In 1927 the figure was 125,000 , while in $1933,90,000$ visited, meaning that not far short of half a million

people were reached over the three events, which all turned profits. ${ }^{158}$ This is all the more impressive given that each exhibition was only open for six days. Though the decline in numbers between 1920 and 1933 might imply a tailing off in popular interest, this might be misleading: the huge figure for 1920 was probably inflated by the popular lucky dip competition, which was not subsequently repeated, while numbers in 1933 may have been 
depressed by a July heatwave which made spending time indoors less attractive. ${ }^{159}$ As a point of comparison, the Ideal Home Exhibition attracted more people - over 600,000 by 1928 though it had more obvious popular appeal, and lasted three and a half weeks rather than one. ${ }^{160}$

It is likely that visitors to the advertising exhibitions represented a social mix. The entry price, a shilling in 1920, rising to $1 / 6$ in 1927 and 1933, though sufficient to deter the poorest, was not extravagant, and there were no extra charges once inside, making it a relatively cheap day out. ${ }^{161}$ Late opening hours - they only closed at $10 \mathrm{pm}$ - also facilitated a wide attendance, while both White City and Olympia were well served by rail links. ${ }^{162}$ The provincial press encouraged its readers to take the trip to London, and though the emphasis was sometimes on business visitors, this was not exclusively so. ${ }^{163}$ Reports often stressed that women were prominent in the crowds of exhibition-goers, noting their interest in the more domestically-focused displays, such as the Advertisers' House and the EMB's cooking demonstrations. ${ }^{164}$ Even children were present, with the organizers issuing "students' tickets" to local schools. ${ }^{165}$

The overall audience for the exhibitions was even larger than the figures suggest. The pageants of 1920 and 1933 were seen by thousands who may not have subsequently visited the exhibitions, while in 1927 Crawford wanted to "make Olympia overflow" by running an Empire Display Week alongside the exhibition, turning London's shop windows into “one vast imperial advertisement." 166 Moreover, the extensive press coverage given the exhibitions meant that, just like world fairs, they were "media events" which could be experienced indirectly by anyone who picked up a newspaper. ${ }^{167}$ Printers' Ink thought that the average reader generally resented articles on advertising in the editorial columns, but the exhibition gave "an opportunity of running in an article on advertisements without annoying anyone.", 168 Royal visits further boosted press coverage in an interwar culture fascinated by royal news: 
these were often the focal point of reports. ${ }^{169}$ Even the BBC patronized the exhibitions of 1927 and 1933 - though its radio services did not carry advertising, its magazines, including the Radio Times, did - and this patronage extended to broadcasting programs about advertising. ${ }^{170}$ The exhibitions thus enabled the dissemination of an immense amount of positive spin to counterbalance the criticisms of advertising which were widespread in interwar British culture. ${ }^{171}$

Press coverage often contained the conversion narratives of sceptics who were won over by the wonders gathered together by the exhibitions. "Let all those who regard Advertising ... as a necessary evil," wrote the Daily Sketch's correspondent, "spend, as I spent yesterday, a leisurely hour wandering around Olympia ... and let them be (as I was!) converted." ${ }^{172}$ Whether the exhibitions actually succeeded in winning many converts is impossible to tell, but Schwarzkopf contends that the kinds of arguments about advertising's benefits propagated by exhibitions can be detected in responses to surveys on attitudes to advertising, suggesting that "public opinion about advertising was reflexively formed using arguments the industry had brought into circulation in the first place." ${ }^{173}$ Moreover, the afterlife of some of the exhibits suggests that they genuinely appealed to the public. Packeteria's successful move to Bentalls has already been noted. And after the 1927 exhibition, the Palace of Beauty was transported to Whiteley's Bayswater department store, where it proved a big draw, and was the subject of an Evening News "Beauty Ballot" competition. ${ }^{174}$ Nevertheless, recent work on exhibitions has stressed that visitors were "active agents" who could interpret exhibitions "on their own terms, confirming, altering, subverting, or ignoring the exhibition's specific ideological projects. ${ }^{, 175}$ Indeed, occasional glimpses can be caught of alternative responses. The publicity parade of 1920 was immediately preceded by a demonstration by 600 unemployed men marching to a drum-andfife band: at one point, they were only fifty yards ahead of the official parade. Slogans on 
their banners, such as "The Scrap-heap of Capitalism," were a direct challenge to the exhibition's optimism. ${ }^{176}$

Yet there is little evidence of active resistance to the exhibitions' messages among visitors. More of a problem was the very principle on which the exhibitions were based - of turning advertising into a spectacle. Though this helped advertisers gain the recognition they craved, it also made the public more conscious of advertising and its workings. This began to seem problematic when this was precisely the strategy pursued by advertising's most vehement critics. 1933 saw the publication of Culture and Environment, F. R. Leavis and Denys Thompson's primer designed to train a critical awareness of modern culture particularly advertising - intended for use in sixth-form classes. ${ }^{177}$ Indeed, the degree of advertising literacy displayed by 1930s children left advertisers reflecting that they were "going to have a devil of a job in another 15 years to break through the shell of sophistication that will protect the buyer from the seller." ${ }^{178}$ Exhibitions may have begun to seem like an unnecessary risk. It is revealing that the 1933 exhibition was not as well supported by the agencies as previous events, and its success was largely due to the enthusiastic involvement of the newspaper press. ${ }^{179}$ Leading agents subsequently became more likely to help organize and promote exhibitions on behalf of other institutions, rather than organizing their own. ${ }^{180}$

As a result, the next comparable event was not until 1962's National Advertising Services Exhibition (“Adex 62”), at Olympia. ${ }^{181}$ Though the exhibition, sponsored by the World's Press News and Advertisers' Review, was swiftly followed up in 1964, these events were on a much smaller scale than their interwar predecessors, and did not try to draw a general audience, despite the centrality of London to Britain's postwar consumer culture. ${ }^{182}$ As a result, they received little mainstream media coverage, and much more modest audiences: fewer than 18,000 came in $1962 .{ }^{183}$ Moves in the 1970 s to mount a major 
advertising exhibition failed because neither the Advertising Association nor the Institute of Practitioners in Advertising were willing to subsidize it. ${ }^{184}$

The industry's renunciation of the public exhibition was not because the exhibition format fell out of favor after the war: despite the availability of new leisure attractions, exhibitions remained popular, with 1951's Festival of Britain proving a hit, and the Ideal Home Exhibition recording its highest ever attendance in $1957 .{ }^{185}$ Nor was it because the industry no longer had to worry about its public image, for advertising came under renewed attack from a new wave of critics spurred on by the arrival of commercial television in 1955. ${ }^{186}$ Instead, the industry changed its approach, employing PR officers, organizing a panel of public speakers to tour the country, and filming documentaries to explain advertising to the public. The shift was telling: these methods cast the audience in a more passive role than the active, critical exhibition-goer. ${ }^{187}$

This suggests that we are dealing with a particular "exhibitory moment" in Britain's advertising history. Why is this moment significant? The industry turned to exhibitions as a means of communicating the power of advertising to multiple audiences. Beginning as a secondary audience of less importance than business clients, the general public became the main target of interwar exhibitions, as advertisers, buoyed by their wartime successes, attempted to establish advertising as an industry of national importance. This involved developing new ways of representing consumer capitalism to the public, undercutting some of the techniques used in previous great exhibitions. While turning advertising into a spectacle was in tune with broader ideas in the interwar period about the sovereign citizenconsumer, exposing advertising in this way to the public gaze was condemned by a growing number of industry insiders as naïve. The reinvention of the advertising exhibition after 1945 as a business-only affair suggests that the industry realized that it may have revealed too much. It still wanted to communicate a message about advertising and its role to the public, 
but now chose safer methods of doing so. The history of advertising exhibitions therefore offers both an invaluable insight into the changing ways in which advertisers understood the publics they purported to serve, and an instructive case study of the complex power relationships involved in the exhibition encounter. 


\footnotetext{
${ }^{1}$ The Times, October 5, 1920, 12.

${ }^{2}$ Daily News, November 30, 1920, 5.

${ }^{3}$ The Star, November 30, 1920, 4. For more on White City, see David Gilbert, "The
} Edwardian Olympics: Suburban Modernity and the White City Games," in The Edwardian Sense: Art, Design, and Performance in Britain, 1901-1910, eds. Morna O’Neill and Michael Hatt (New Haven, 2010), 73-97.

${ }^{4}$ Throughout the article I use the term "advertising industry" as a shorthand to refer to the wide group of interests involved in the production and distribution of advertising. This is not supposed to imply the existence of a cohesive sense of identity, however: as the article makes clear, one of the purposes of advertising exhibitions was to help foster this identity.

${ }^{5}$ Paul Readman, 'Landscape Preservation, ‘Advertising Disfigurement,' and English National Identity, c. 1890-1914," Rural History 12 (2001): 61-83; T. R. Nevett, Advertising in Britain: A History (London, 1982), 117.

${ }^{6}$ There were 83 agencies in Britain by 1896: Paul Jobling, Advertising Menswear: Masculinity and Fashion in the British Media since 1945 (London, 2014), 33.

${ }^{7}$ Liz McFall, Advertising: A Cultural Economy (London, 2004), 110-18.

${ }^{8}$ Francis Goodall, "Marketing Consumer Products before 1914: Rowntrees and Elect Cocoa," in Markets and Bagmen: Studies in the History of Marketing and British Industrial Performance 1830-1939, ed. R. P. T. Davenport-Hines (Aldershot, 1986), 16-56.

${ }^{9}$ Richard Altick, The Shows of London (Cambridge, MA, 1978), 509.

${ }^{10}$ Sophie Forgan, "From Modern Babylon to White City: Science, Technology and Urban Change in London, 1870-1914," in Urban Modernity: Cultural Innovation in the Second Industrial Revolution, eds. Miriam R. Levin et al. (Cambridge, MA, 2010), 104-5. 
${ }^{11}$ Anne Clendinning, Demons of Domesticity: Women and the English Gas Industry, 18891939 (Aldershot, 2004), chapter 2; Derek J. Oddy, "Food Quality in London and the Rise of the Public Analyst, 1870-1939," in Food and the City in Europe since 1800, eds. Peter J. Atkins et al. (London, 2016), 95.

${ }^{12}$ Glen Norcliffe, Critical Geographies of Cycling: History, Political Economy and Culture (London, 2016), 10; David Jeremiah, Representations of British Motoring (Manchester, 2007), 19.

${ }^{13}$ John Glanfield, Earls Court and Olympia: From Buffalo Bill to the "Brits" (Stroud, 2003), 44.

${ }^{14}$ A notable exception is Deborah Sugg Ryan, "Spectacle, the Public, and the Crowd: Exhibitions and Pageants in 1908," in O'Neill and Hatt (eds), The Edwardian Sense, 43-71. By contrast, the literature on international exhibitions is voluminous, with one historian recently estimating that an average of 63 works of "exposition studies" are published annually: Alexander C. T. Geppert, Fleeting Cities: Imperial Expositions in Fin-de-Siècle Europe (Basingstoke, 2010), 11.

${ }^{15}$ Deborah S. Ryan, “The Daily Mail Ideal Home Exhibition and Suburban Modernity, 19081951” (PhD diss., University of East London, 1995), 35-6.

${ }^{16}$ The Times, October 25, 1909, 15.

${ }^{17}$ For more on the audience for early twentieth-century mass culture, see D. L. LeMahieu, $A$ Culture for Democracy: Mass Communication and the Cultivated Mind in Britain between the Wars (Oxford, 1988).

${ }^{18}$ Stefan Schwarzkopf, "Respectable Persuaders: The Advertising Industry and British Society, 1900-1939” (PhD diss., Birkbeck College, University of London, 2008), chapter 3. ${ }^{19}$ Peter H. Hoffenberg, An Empire on Display: English, Indian, and Australian Exhibitions from the Crystal Palace to the Great War (Berkeley, 2001), 3. 
${ }^{20}$ Paul Greenhalgh, Ephemeral Vistas: The Expositions Universelles, Great Exhibitions and World's Fairs, 1851-1939 (Manchester, 1988), 41-2.

${ }^{21}$ Smaller advertising exhibitions were held elsewhere in the country in this period, including Newcastle (1921) and Glasgow (1926), but this article focuses on the major London events.

${ }^{22}$ Ruth E. Iskin, The Poster: Art, Advertising, Design, and Collecting, 1860s-1900s (Hanover, NH, 2014), chapter 1.

${ }^{23}$ The Times, February 22, 1899, 13; Leeds Mercury, March 13, 1899, 7.

${ }^{24}$ Leeds Mercury, April 22, 1899, 6; For a descriptive account of 1899, see Diana and Geoffrey Hindley, Advertising in Victorian England, 1837-1901 (London, 1972), 55-8.

${ }^{25}$ Other exhibition organisers preferred London for similar reasons: Elizabeth A. Darling,

““To Induce Humanitarian Sentiments in Prurient Londoners:' The Propaganda Activities of London's Voluntary Housing Associations in the Inter-War Period," London Journal 27 (2002): 51-2. Yet there were many exhibition venues outside London: Ryan, "Exhibitions and Pageants," $67 \mathrm{fn} 21$.

${ }^{26}$ The Poster, 4 (June 1900), 143. For more on posters as art, see John Hewitt, "The Poster and the Poster in England in the 1890s," Victorian Periodicals Review 35 (2002): 37-62.

${ }^{27}$ The Times, October 16, 1909, 7.

${ }^{28}$ The Times, July 5, 1907, 11.

${ }^{29}$ Daily Mirror, October 18, 1910, 17.

${ }^{30}$ The Times, October 15, 1910, 5.

${ }^{31}$ Advertising World, November 1910, 596.

${ }^{32}$ Advertising World, November 1912, 617.

${ }^{33}$ Advertising World, July 1912, 18-19.

${ }^{34}$ Printers' Ink, November 1913, 175.

${ }^{35}$ Advertiser's Weekly, September 27, 1913, 374-5. 
${ }^{36}$ Advertiser's Weekly, August 16, 1913, 130-1.

${ }^{37}$ Printers' Ink, May 1914, 187; The Times, April 28, 1914, 14.

${ }^{38}$ Advertiser's Weekly, December 3, 1920, 360.

${ }^{39}$ Louis Kaufman, Advertiser's Weekly, September 10, 1920, 300.

${ }^{40}$ Gary S. Messinger, British Propaganda and the State in the First World War (Manchester, 1992), chapter 14.

${ }^{41}$ Sir Eric Campbell Geddes, Advertising World, December 1920, 687.

${ }^{42}$ Jobling, Advertising Menswear, 34.

${ }^{43}$ There was an exhibition of advertising arts at the British Empire Exhibition at Wembley in 1924-25: Lawrence Weaver, Exhibitions and the Arts of Display (London, 1925), 49.

${ }^{44}$ Stephen Constantine, "Bringing the Empire Alive: The Empire Marketing Board and Imperial Propaganda, 1926-33," in Imperialism and Popular Culture ed. John MacKenzie (Manchester, 1986), 192-231.

${ }^{45}$ Nevett, Advertising in Britain, 155. Olympia also hosted the annual advertising convention which ran alongside the exhibition.

${ }^{46}$ Advertiser's Weekly, December 17, 1920, 446; Daily Mail, July 14, 1927, 6; Daily Mail, July 18, 1927, 11; Daily Mail, July 19, 1927, 7.

${ }^{47}$ Advertiser's Weekly, July 19, 1927, supplement, ii.

${ }^{48}$ Again, the advertising convention ran parallel to the exhibition.

${ }^{49}$ R. Bernard, Advertiser's Weekly, March 2, 1933, 254.

${ }^{50}$ The exhibition had an Empire Section with its own organising sub-committee, and a “compact block of its own:” Advertiser's Weekly, March 2, 1933, 266.

${ }^{51}$ Advertiser's Weekly, June 15, 1933, 314. The exhibition also had a broader focus on marketing, reflected in its new title, the "Advertising and Marketing Exhibition." 
${ }^{52}$ Michele H. Bogart, Artists, Advertising, and the Borders of Art (Chicago, 1995), 50-1, 128 33; Mienke Simon Thomas, Dutch Design: A History (London, 2008), chapter 2. ${ }^{53}$ San Francisco Call, January 27, 1910, 5; San Francisco Call, June 26, 1910, 60; Evening Public Ledger, February 23, 1916, 4. The third convention of Advertising Men of Australia and New Zealand in Melbourne in 1921 also boasted an exhibition: The Argus, August 19, 1921, 6; The Argus, August 20, 1921, 16.

${ }^{54}$ See, for example, Higham's verdict: Advertiser's Weekly, December 24, 1920, 482.

${ }^{55}$ Advertiser's Weekly, July 19, 1927, 256.

${ }^{56}$ The limitations of the Americanisation thesis are discussed in Sean Nixon, Hard Sell: Advertising, Affluence and Transatlantic Relations, c. 1951-69 (Manchester, 2013).

${ }^{57}$ Advertiser's Weekly, November 30, 1920, 319.

${ }^{58}$ Advertiser's Weekly, September 17, 1920, 333.

${ }^{59}$ Walter Benjamin, "Paris - Capital of the Nineteenth Century," 81-2: www.no-where.org.uk/paris\%20capital.pdf; Thomas Richards, The Commodity Culture of Victorian England: Advertising and Spectacle, 1851-1914 (London, 1991), 59.

${ }^{60}$ Advertiser's Weekly, May 7, 1920, 168.

${ }^{61}$ For more on criticisms of advertising, see Nevett, Advertising in Britain, 110-20, 160-8; John Carey, The Intellectuals and the Masses: Pride and Prejudice among the Literary Intelligentsia, 1880-1939 (Chicago, 2002).

${ }^{62}$ Louis Kaufman, Advertiser's Weekly, September 10, 1920, 300.

${ }^{63}$ Advertiser's Weekly, December 3, 1920, 371.

${ }^{64}$ Roy Church. "Advertising Consumer Goods in Nineteenth-Century Britain:

Reinterpretations," Economic History Review 53 (2000): 621-45; Stefan Schwarzkopf, “Turning Trademarks into Brands: How Advertising Agencies Practiced and Conceptualized 
Branding, 1890-1930," in Trademarks, Brands, and Competitiveness, eds. Teresa da Silva Lopes and Paul Duguid (London, 2010), 165-93.

${ }^{65}$ Anon., Things to Know about Trade-Marks (New York, 1911), chapter 3.

${ }^{66}$ Advertiser's Weekly, October 18, 1913, 16; Advertiser's Weekly, October 25, 1913, 80.

${ }^{67}$ Daily News, November 29, $1920,5$.

${ }^{68}$ Morning Post, November 29, 1920, 5.

${ }^{69}$ The Star, November 27, 1920, 4; Evening Standard, November 27, 1920, 1.

${ }^{70}$ Barrington Hooper, Advertiser's Weekly, November 26, 1920, 273.

${ }^{71}$ Daily Mail, November 29, 1920, 10.

${ }^{72}$ Advertiser's Weekly, November 30, 1920, 351; Advertiser's Weekly, December 3, 1920, 361.

${ }^{73}$ Scott Cohen, "The Empire from the Street: Virginia Woolf, Wembley and Imperial Monuments," MFS Modern Fiction Studies 50 (2004): 89-90.

${ }^{74}$ Ulric B. Walmsley, Advertiser's Weekly, July 15, 1927, 110.

${ }^{75}$ Daily News, July 19, 1927, 5.

${ }^{76}$ Advertiser's Weekly, July 19, 1927, 240. This may have been effective: in "The Rummy Affair of Old Biffy," Bertie Wooster is unimpressed by Wembley’s Palace of Beauty: "I maintain that a lovely woman loses a lot of her charm if you have to stare at her in a tank." P. G. Wodehouse, The World of Jeeves (London, 1972), 257.

${ }^{77}$ Advertising World, July 1927, 338; J. Harvey-Smith, Advertiser's Weekly, July 22, 1927, 282.

${ }^{78}$ Advertiser's Weekly, July 22, 1927, 274. Reports claimed that it was the most popular attraction with the public: Daily News, July 19, 1927, 5.

${ }^{79}$ Morning Post, July 21, 1927, 12. 
${ }^{80}$ Richard Hornsey, "Penguins' Progress: Brand Mascots and Utopian Mass Consumption in Interwar Britain” (under review).

${ }^{81}$ Advertising World, November 1920, 518; Advertising World, December 1920, 738; Daily

Herald, December 2, 1920, 3. For an artist's impression of the ball, see Advertiser's Weekly,

December 3, 1920, 362.

${ }^{82}$ Daily Mirror, July 23, 1927, 3.

${ }^{83}$ Daily Sketch, July 18, 1933, 9; News Chronicle, July 11, 1933, 3.

${ }^{84}$ For more on this, see Hornsey, "Penguins' Progress."

${ }^{85}$ Advertiser's Weekly, July 8, 1927, 38-9.

${ }^{86}$ Advertiser's Weekly, July 22, 1927, 274.

${ }^{87}$ Advertising World, November 1920, 518.

${ }^{88}$ The Times, November 27, 1920, 7.

${ }^{89}$ Philip Emanuel, Advertiser's Weekly, July 8, 1927, 38-9.

${ }^{90}$ Advertising World, August 1927, 522.

${ }^{91}$ Richards, Commodity Culture, 186.

${ }^{92}$ Advertising, June 1899, 476; The Times, July 17, 1933, 9. For more on sky advertising, see James Taylor, "Written in the Skies: Advertising, Technology, and Modernity in Britain since 1885," Journal of British Studies 55 (2016): 750-80.

${ }^{93}$ Advertiser's Weekly, October 18, 1913, 30.

${ }^{94}$ Emily Robinson, "Defining Progressive Politics: Municipal Socialism and Anti-Socialism in Contestation, 1889-1939," Journal of the History of Ideas 76 (2015): 625.

${ }^{95}$ Advertising World, December 1912, 678; Daily Mail, December 9, 1912, 7.

${ }^{96}$ Evening News, July 18, 1927, 1; Morning Post, July 19, 1933, 8.

${ }^{97}$ See, for example, Advertiser's Weekly, March 2, 1933, 258. 
${ }^{98}$ British Pathé, “Advertising Exhibition” (1920):

https://www.youtube.com/watch?v=O7NavYaNsWY

${ }^{99}$ Forgan, "Modern Babylon," 109-110. See also Darling, "Propaganda Activities," 52-5;

Mark Whitehead, "Domesticating Technological Myth: Gender, Exhibition Spaces and the

Clean Air Movement in the UK," Social \& Cultural Geography 9 (2008): 644.

${ }^{100}$ Advertiser's Weekly, July 15, 1927, 136.

${ }^{101}$ Advertiser's Weekly, July 18, 1933, supplement, iv.

102 Bernhard Rieger and Martin Daunton, 'Introduction', in Meanings of Modernity: Britain from the Late-Victorian Era to World War II, eds. Martin Daunton and Bernhard Rieger (Oxford, 2001), 8 .

${ }^{103}$ The Times, April 28, 1899, 4; Advertising World, November 1912, 534; Advertiser's Weekly, October 1, 1920, 4.

${ }^{104}$ Morning Post, July 18, 1927, 12; Rieger and Daunton, 'Introduction', 6. See also Michael T. Saler, The Avant-Garde in Interwar England: Medieval Modernism and the London Underground (Oxford, 2001).

${ }^{105}$ Forgan, "Modern Babylon," 110.

${ }^{106}$ Rosalind H. Williams, Dream Worlds: Mass Consumption in Late Nineteenth-Century France (Berkeley, 1982), 69, 71.

${ }^{107}$ Advertising World, January 1913, 34; Advertising World, June 1912, 649-50.

${ }^{108}$ Pictures of many of the kiosks can be found in Weaver, Exhibitions and the Arts of Display.

${ }^{109}$ Advertiser's Weekly, March 2, 1933, 256.

${ }^{110}$ Advertiser's Weekly, July 19, 1927, 198.

${ }^{111}$ Daily Mail, July 11, 1927, 4; Daily Mail, July 14, 1927, 6. 
${ }^{112}$ Matthew Hilton, Consumerism in Twentieth-Century Britain: The Search for a Historical Movement (Cambridge, 2003), 99-107.

113 Advertiser's Weekly, March 2, 1933, 250. For more on Crawford, see Stefan Schwarzkopf, "Creativity, Capital and Tacit Knowledge: The Crawford Agency and British Advertising in the Interwar Years," Journal of Cultural Economy 1 (2008): 181-97.

${ }^{114}$ Advertiser's Weekly, July 27, 1933, 226.

${ }^{115}$ Sinclair Wood, Advertiser's Weekly, July 13, 1933, 56-8.

${ }^{116}$ Advertiser's Weekly, July 18, 1933, supplement, ii.

${ }^{117}$ Daily Herald, July 15, 1933, 9.

${ }^{118}$ Advertising World, September 1933, 212.

${ }^{119}$ For more on the design of twentieth-century chain stores, see Janice Winship, "New Disciplines for Women and the Rise of the Chain Store in the 1930s," in All the World and Her Husband: Women in Twentieth-Century Consumer Culture, eds. Maggie Andrews and Mary M. Talbot (London, 2000), 36-7. The exhibitions' influence is underlined by the fact that Emberton went on to design several important modernist retail landmarks, including Simpson Piccadilly in 1936, hailed as London's first department store for men, and HMV's flagship Oxford Street store in 1939: Bronwen Edwards, “A Man’s World? Masculinity and Metropolitan Modernity at Simpson Piccadilly," in Geographies of British Modernity: Space and Society in the Twentieth Century, eds. David Gilbert et al. (Malden, MA, 2003), 151-67. ${ }^{120}$ Daniel Stephen, The Empire of Progress: West Africans, Indians, and Britons at the British Empire Exhibition, 1924-25 (New York, 2013), 18.

${ }^{121}$ Daily Herald, July 20, 1933, 4; Advertiser's Weekly, July 22, 1927, 282.

${ }^{122}$ Williams, Dream Worlds, 67.

${ }^{123}$ Quoted in Geppert, Fleeting Cities, 283-4.

${ }^{124}$ The Times, May 24, 1909, 13. 
${ }^{125}$ Daily Mirror, February 12, 1908, 5; Advertiser's Weekly, September 17, 1920, 332.

${ }^{126}$ Advertiser's Weekly, July 19, 1927, 206; Advertiser's Weekly, March 2, 1933, 256.

${ }^{127}$ The Times, November 30, 1920, 9; E. L. Fletcher, Advertising World, December 1920, 698.

${ }^{128}$ The Rise of Marketing and Market Research, eds. Harmut Berghoff et al. (New York, 2012).

${ }^{129}$ Advertiser's Weekly, July 22, 1927, 275; Advertiser's Weekly, July 19, 1927, 206; News Chronicle, July 11, 1933, 3.

${ }^{130}$ The aim was to assess the influence of colour in advertising: Daily Mail, July 16, 1927, 10.

${ }^{131}$ Advertiser's Weekly, August 5, 1927, 399, 410.

${ }^{132}$ Richards, Commodity Culture, 57. See also Williams, Dream Worlds, 60; Russell Lewis, "Everything Under One Roof: World's Fairs and Department Stores in Paris and Chicago," Chicago History 12 (1983): 30-5.

${ }^{133}$ Louise Purbrick, "Introduction," in The Great Exhibition of 1851: New Interdisciplinary Essays, ed. Louise Purbrick (Manchester, 2001), 15.

${ }^{134}$ J. C. Akerman, Advertising World, February 1927, 490.

${ }^{135}$ Weaver, Exhibitions and the Arts of Display, 101. The factory was also popular in US trade shows around this time: Roland Marchand, Creating the Corporate Soul: The Rise of Public Relations and Corporate Imagery in American Big Business (Berkeley, 2000), chapter 7.

${ }^{136}$ Belfast News-Letter, April 24, 1899, 7.

${ }^{137}$ Advertiser's Weekly, July 18, 1933, 136; Daily Herald, July 18, 1933, 4.

${ }^{138}$ The Times, December 12, 1912, 4.

${ }^{139}$ Advertising World, August 1927, 520. 
${ }^{140}$ Advertiser's Weekly, July 19, 1927, 240.

${ }^{141}$ Advertiser's Weekly, December 3, 1920, 368.

${ }^{142}$ Advertiser's Weekly, July 19, 1927, 256; Morning Post, July 19, 1927, 7.

${ }^{143}$ Greenhalgh, Ephemeral Vistas, 30. See also John M. Mackenzie, Propaganda and

Empire: The Manipulation of British Public Opinion, 1880-1960 (Manchester, 1984), 97.

144 Tony Bennett, “The Exhibitionary Complex,” New Formations 4 (1988): 80.

${ }^{145}$ Daily Mail, July 16, 1927, 10. See also Daily Mail, July 18, 1927, 11.

${ }^{146}$ Daily Express, July 18, 1927, 8.

147 The idea of the sovereign consumer is explored in Stefan Schwarzkopf, "The Consumer as 'Voter,' ‘Judge,' and 'Jury:' Historical Origins and Political Consequences of a Marketing Myth," Journal of Macromarketing 31 (2011): 8-18; LeMahieu, Culture for Democracy, 1417.

${ }^{148}$ Bennett, "Exhibitionary Complex," 79. This approach was typical of interwar exhibitions: the British Empire Exhibition invited visitors "to inspect the Empire from end to end:" David Gilbert and Felix Driver, "Capital and Empire: Geographies of Imperial London,"

GeoJournal 51 (2000): 31.

${ }^{149}$ Advertiser's Weekly, August 23, 1913, 161.

${ }^{150}$ Daily Express, October 17, 1913, 6.

${ }^{151}$ Daily Mail, July 18, 1933, 9.

${ }^{152}$ H. V. Morton, Daily Express, July 18, 1927, 2 (emphasis added). For more on the language of "the Man in the Street," see James Thompson, British Political Culture and the Idea of "Public Opinion," 1867-1914 (Cambridge, 2013), 35-41.

${ }^{153}$ E. L. Fletcher, Advertising World, December 1920, 696.

${ }^{154}$ Advertiser's Weekly, March 2, 1933, 250.

155 Advertiser's Weekly, March 9, 1933, 296. 
${ }^{156}$ Adrian Bingham and Martin Conboy, Tabloid Century: The Popular Press in Britain, 1896 to the present (Oxford, 2015), 10-11; Daily Herald, July 19, 1927, 4. It received the 1933 exhibition with similar warmth: Daily Herald, July 17, 1933, 8.

${ }^{157}$ Schwarzkopf, "Respectable Persuaders," 130.

${ }^{158}$ The Times, December 6, 1920, 7; Advertiser's Weekly, July 29, 1927, 386; Advertiser's Weekly, October 26, 1933, 120; Advertiser's Weekly, July 29, 1927, 345; Advertiser's Weekly, October 26, 1933, 120.

${ }^{159}$ The crush of visitors at White City had been so great that the entry price was raised on the penultimate day of the exhibition to 5 shillings to ensure that commercial visitors could transact business comfortably.

${ }^{160}$ Ryan, "Ideal Home Exhibition," 324.

161 The exception was 1933's "film test," for which entrants paid two shillings, but received a photograph as a souvenir: Daily Herald, July 15, 1933, 9.

${ }^{162}$ Forgan, "Modern Babylon,” 104-6.

${ }^{163}$ See, for example, Hull Daily Mail, November 26, 1920, 5; Leeds Mercury, July 18, 1927 , 7; Yorkshire Post, July 18, 1933, 6.

${ }^{164}$ The Times, November 30, 1920, 9; The Scotsman, July 25, 1927, 12.

165 Advertiser's Weekly, November 5, 1920, 187.

166 Advertiser's Weekly, July 15, 1927, 112; Advertiser's Weekly, May 13, 1927, 214.

${ }^{167}$ Warren Susman, "Ritual Fairs," Chicago History 12 (1983): 4-7.

${ }^{168}$ Printers' Ink, November 1913, 162.

${ }^{169}$ See, for example, Morning Post, December 4, 1920, 6; Daily News, July 20, 1927, 3; Evening News, July 18, 1933, 1. For more on royalty and the press, see Bingham and Conboy, Tabloid Century, chapter 3. 
${ }^{170}$ Advertiser's Weekly, July 29, 1927, 348; Advertising World, July 1927, 338; Advertiser's Weekly, July 21, 1933, 214; Advertising World, August 1933, 132.

${ }^{171}$ For examples of scathing attacks on advertising in popular fiction, see Ethel Mannin, Sounding Brass (1925), Dorothy L. Sayers, Murder Must Advertise (1933), and George Orwell, Keep the Aspidistra Flying (1936).

${ }^{172}$ Daily Sketch, July 18, 1927, 2. See also Advertiser's Weekly, December 3, 1920, 372; Advertiser's Weekly, July 19, 1927, 200.

${ }^{173}$ Schwarzkopf, "Respectable Persuaders," 169-70. For one such survey, see File Report A10, Reactions to Advertising: An Inquiry by Mass-Observation, December 1938, Mass Observation Online.

${ }^{174}$ Evening News, July 25, 1933, 7; Evening News, July 29, 1933, 2-3.

${ }^{175}$ Stephen, Empire of Progress, 20.

${ }^{176}$ Daily Herald, November 29, 1920, 2.

${ }^{177}$ Christopher Hilliard, English as a Vocation: The Scrutiny Movement (Oxford, 2012), chapter 2. For a review stressing its educational value see Hugh Ross Williamson, "Notes at Random," The Bookman, March 1933, 483.

${ }^{178}$ E. Searle Austin, Advertising Display, cutting in London Metropolitan Archives, ACC/3527/414: Advertisements for Lyons designed by children at North Finchley County Secondary School, 1935.

${ }^{179}$ Advertising World, August 1933, 130.

${ }^{180}$ Pritchard and Wood were the organisers of the Special Areas Exhibition at Charing Cross station in 1936, while Crawford was the PR officer for the Live Architecture Exhibition element of the Festival of Britain: Denis Linehan, “A New England: Landscape, Exhibition and Remaking Industrial Space in the 1930s," in Geographies of British Modernity, 140-1; 
Matthew Hollow, "Utopian Urges: Visions for Reconstruction in Britain, 1940-1950," Planning Perspectives 27 (2012): 577.

181 The 1950s only saw small-scale exhibitions which tended to focus on art in advertising: Winston Fletcher, Powers of Persuasion: The Inside Story of British Advertising: 1951-2000 (Oxford, 2008), 7-8; The Times, November 22, 1955, 11.

182 David Gilbert, “'The Youngest Legend in History:' Cultures of Consumption and the Mythologies of Swinging London," London Journal 31 (2006): 1-14.

${ }^{183}$ World's Press News and Advertisers' Review, September 21, 1962, 3.

${ }^{184}$ Fletcher, Powers of Persuasion, 117-18.

${ }^{185}$ Becky Conekin, The Autobiography of a Nation: The 1951 Festival of Britain (Manchester, 2003); Ryan, "Ideal Home Exhibition," 7.

${ }^{186}$ Hilton, Consumerism, 199-201; Sean Nixon, “'Salesmen of the Will to Want: Advertising and its Critics in Britain, 1951-1967," Contemporary British History 24 (2010): 213-33. ${ }^{187}$ Stefan Schwarzkopf, “They do it with Mirrors: Advertising and British Cold War Consumer Politics," Contemporary British History 19 (2005): 142-3. 